\title{
A case with primary signet ring cell adenocarcinoma of the prostate and review of the literature
}

Keywords: carcinoma, hypertension, pancytopenia, physical examination, duodenoscopy, signet ring cell, adenocarcinoma, prostates

Abbreviations: NA, not applicate; H, hormone; R, radiotherapy; $\mathrm{RP}$, radical prostatectomy; $\mathrm{CT}$, chemotherapy

\section{Case report}

Primary signet ring cell carcinoma (SRCC) constitutes approximately $3-4 \%$ of the stomach cancers; it is very rare variant of prostate carcinoma. It is estimated to occur in $2.5 \%$ of cases of prostate adenocarcinoma. ${ }^{1}$ Prostate SRCC is diagnosed by eliminating of other organs such as colon and stomach, pancreas, breast, thyroid and bladder. Prognosis is worse than the adenocarcinoma. Only 69 cases have been reported in the English literature since 1979. ${ }^{2}$ We recently diagnosed a case of primary SRCC of the prostate by this we review previous reports. Based on our case, we present the pathologic, clinical and therapeutic aspects of this rare entity.

In July 2016 an 83-year-old male was referred to our institution for evaluation of a serum prostate antigen (PSA) level of $8,79 \mathrm{ng} / \mathrm{ml}$. The patient had personal history of hypertension and pancytopenia. He had personal or family history of malignancy. Levels of serum prostatic acid phosphatase (PAP) and carcinoembryonic antigen (CEA) were normal. Physical examination, including digital rectal exam, demonstrated invasion of unilateral seminal vesicles. A prostate needle biopsy was carried out. Histologically, biopsy demonstrated an adenocarcinoma with predominantly of the signet ring cell component, Gleason $8(4+4)$ in left prostate lobe $(65 \%)$. Duodenoscopy and colonoscopy were performed for evaluation of the gastrointestinal and no evidence of tumour was found. Overall, this tumour was regarded as primary SRCC of the prostate. Radionuclide bone scan and computed tomography body were negative for metastatic disease. The patient was diagnosed with primary SRCC of the prostate (T3bN0M0).

In multidisciplinary committee we decided androgen blockade One month later of blockade, his serum PSA level was reduced to $0.1 \mathrm{ng} / \mathrm{mL}$. He was alive with no evidence of disease 8 months after blockade. As in common prostatic adenocarcinoma, the tumor retained hormonal dependency, showing a dramatic response to androgen deprivation therapy.

\section{Discussion}

The majority of prostatic cancers are acinar adenocarcinomas. Histological variants of prostatic carcinoma have been variably defined. One approach is to consider two groups of variants. The first group comprises histological variants of acinar adenocarcinoma (atrophic, pseudohyperplastic, foamy, colloid, signet ring, oncocytic and lymphoepithelioma-like carcinomas) and the second group nonacinar carcinoma variants $(5-10 \%){ }^{3}$

The term "signet ring cell" is used to describe cells that have their nuclei displaced by an intracytoplasmic vacuole. These cells are more frequently seen focally within otherwise high-grade prostate cancers and should be considered as part of the Gleason scoring. ${ }^{3}$

\author{
Volume 7 Issue 6 - 2017 \\ De La Pinta C, Martin M \\ Department of Radiation Oncology, Hospital Ramon Y Cajal, \\ Spain \\ Correspondence: De La Pinta C, Department of Radiation \\ Oncology, Hospital Ramn Y Cajal, Spain, \\ Email cdelapinta88@gmail.com
}

Received: March 20, 2017| Published: April 18, 2017

But, Guerin and colleagues ${ }^{1}$ suggested that SRCC should be classified as a variant of high-grade adenocarcinoma rather than a separate histologic classification. The largest series to date has shown poor survival. Clinically, primary SRCC of the prostate presents with the same classic obstructive and irritative symptoms or asymptomatic as other common adenocarcinomas, the diagnosis of primary prostatic SRCC of the prostate is certainly a histologic diagnosis that can be done using needle biopsy, endoscopic resection specimens or radical prostatectomy. To diagnose primary SRCC of the prostate, tumour should contain more than $25 \%$ of these cells. In our patient, the gastrointestinal workup showed no evidence of tumour. Therefore, we assumed that the prostate was the primary source of the tumour. Some series show carcinoembryonic antigen (CEA) positive in $20 \%$ of the cases (10) whereas PSA and prostate specific acid phosphatase (PSAP) were positive in $87 \%$ of the cases $^{4}$ and positive staining with periodic acid-schiff stain (PAS) was positive in $60 \%$, with alcian blue $60 \%$ and with mucicarmin $50 \%$. Clinically, SRCC of the prostate is usually diagnosed in an advanced stage of disease through elevated PSA levels. However, some cases with SRCC have high carcinoembryonic antigen immunoreactivity, while PSA is negative.

We reviewed previous English reports and found 69 reported cases of primary SRCC of the prostate. Table 1 shows the results of special treatment of more important cases. Because of its rarity, no recommended treatment has been established. Conventional therapy for prostate cancer has generally been used, involving variable combinations of hormonal therapy, radiation and surgery. Nevertheless, on the basis of the available cases, the effectiveness of hormonal therapy is unpredictable. To date, no definite explanation for this variability has been given however; Lilleby et al. ${ }^{12}$ reported a case of SRCC treated with Neoadjuvant hormonal therapy and radiotherapy with a favorable response at 12 months of follow-up. Moreover, Kanematsu and Hiura ${ }^{6}$ reported a case of primary SRCC with an undetectable PSA level 3 years after a radical prostatectomy and preoperative androgen blockade. Akagashi et al. ${ }^{8}$ further reported a case of an undetectable PSA level 20 months after treatment with 
complete androgen blockade. No single treatment modality is ideal for treating SRCC, but we consider that more aggressive multimodal treatment should be considered. Androgen deprivation therapy in Yamamoto study was not effective and therefore that systemic chemotherapy (due to possible gastrointestinal tract origin) and irradiation therapy should be recommended..$^{20,21}$ In our case, treatment response to androgen blockade was good.

Table I Results of special treatment of more important cases

\begin{tabular}{|c|c|c|c|c|c|c|}
\hline \multirow[b]{2}{*}{ Yoshimura et al. ${ }^{5}$} & \multirow{2}{*}{$\begin{array}{l}\text { Stage } \\
\text { T3NOMO }\end{array}$} & \multicolumn{2}{|c|}{ Age PSA/CEA } & \multirow{2}{*}{$\begin{array}{l}\text { treatment } \\
H+R\end{array}$} & \multicolumn{2}{|c|}{ Follow up months Status } \\
\hline & & 65 & $+/ \mathrm{NA}$ & & 100 & Alive CR \\
\hline Kanematsu et al. ${ }^{6}$ & T2NOMO & 76 & $237 /-$ & $\mathrm{H}+\mathrm{RP}$ & 36 & Alive \\
\hline Ishizu $\mathrm{K}^{7}$ & E-IV ParaAO lymph nodes & 67 & $46,2 / N A$ & $\mathrm{H}$ & 2 & Alive $C R$ \\
\hline Akagashi $\mathrm{K}^{8}$ & T4N0M0 & 72 & $+/ \mathrm{NA}$ & $\mathrm{H}$ & 20 & Alive CR \\
\hline Fujita ${ }^{9}$ & T2aNOMO & 75 & $9,3 /-$ & $\mathrm{H}+\mathrm{RP}$ & 12 & Alive \\
\hline Uemura $M^{10}$ & Local stage & 76 & 28/NA & RP & 13 & Alive \\
\hline Derouiche"l & $\mathrm{T} 2$ & 85 & $9,1 /-$ & $\mathrm{H}$ & 18 & Alive \\
\hline Lilleby ${ }^{12}$ & T3bNOMO & 70 & $27 /-$ & $\mathrm{H}+\mathrm{R}$ & 12 & Alive \\
\hline \multirow[t]{5}{*}{ Matsuoka $Y^{13}$} & cT4NIMIc & 62 & $364.7 / \mathrm{NA}$ & $\mathrm{H}$ & 15 & Died \\
\hline & cTI & 58 & NA & $R$ & Median 30 & 24 \\
\hline & T4MI & 82 & NA & $\mathrm{H}$ & & 5 \\
\hline & T4MI & 68 & NA & $\mathrm{H}$ & & 12 \\
\hline & T3MI & 65 & NA & $\mathrm{H}$ & & 24 \\
\hline \multirow[t]{5}{*}{ Warner et al..$^{14}$} & T3a & 66 & NA & RP & & 108 \\
\hline & cT2a & 67 & 1,9 & $\mathrm{H}+\mathrm{R}$ & & Alive at 48 \\
\hline & T3b & 79 & 5,9 & $\mathrm{CP}$ & & 4 \\
\hline & T3b & 50 & NA & $R P+R$ & & Alive at 36 \\
\hline & $\mathrm{T} 2 \mathrm{~b}$ & 59 & 4,8 & $\mathrm{RP}+\mathrm{H}$ & & Alive at 12 \\
\hline Hashimoto $Y^{15}$ & T3N2M2 & 61 & 0,19 & CT & 16 & Died \\
\hline Bonetti LR ${ }^{16}$ & - & 70 & + & $\mathrm{H}+\mathrm{R}$ & 11 & Died \\
\hline Kwon ${ }^{17}$ & T2bNOMIb & 61 & 14,7 & $\mathrm{H}$ Progression at $9 \mathrm{~m}$ docetaxel & 11 & Died \\
\hline Celik et al. ${ }^{18}$ & E-IV Bone metastases & 66 & 6658 & $\mathrm{H}+$ docetaxel & 22 & Died \\
\hline Kim et al. ${ }^{19}$ & T3bNOMO & 56 & 0,64 & $\mathrm{RP}+\mathrm{CT}$ Progression & 24 & Died \\
\hline
\end{tabular}

$N A$, not applicate; $H$, hormone; $R$, radiotherapy; $R P$, radical prostatectomy; $C T$, chemotherapy

Prostate specific antigen values and treatment modalities were not determinants of survival. Many authors reported the poor prognosis of prostate SRCC, with less treatment response and poor prognosis when compared to the classical type of the prostate adenocarcinoma. It is difficult to define an optimum treatment strategy for SRCC of the prostate from the existing data, early diagnosis and local treatment of the prostate when there is no evidence of metastatic disease might improve prognosis. Fujita et al. ${ }^{9}$ reported that, in primary SRCC of the prostate, the survival rate is about $55 \%$ at 3 years and decreases to $12 \%$ at 5 years. The same study revealed that prognosis is only related to the stage of the disease at diagnosis and more of these patients present with stage IV.

\section{Conclusion}

We conclude that signet-ring-cell carcinoma of the prostate is a variant of poorly differentiated adenocarcinoma of the prostate (high grade).$^{22}$ Therefore, some authors have hypothesized that prostatic SRCC is not always an aggressive disease. ${ }^{8}$ The present case of prostatic SRCC responded well to medical therapy, however, tumors can recur after a long period of time. We recommend early, careful assessment for appropriate diagnosis.

\section{Funding}

None.

\section{Acknowledgements}

None.

\section{Conflicts of interests}

The authors declare that there is no conflict of interest.

\section{References}

1. Guerin D, Hasan N, Keen CE. Signet ring cell differentiation in adenocarcinoma of the prostate: a study of five cases. Histopathology. $1993 ; 22(4): 367-371$.

2. Uyama T, Moriwaki S. Papillary and mucus-forming adenocarcinomas of prostate. Urology. 1979;13(4): =432-444.

3. Humphrey PA. Histological variants of prostatic carcinoma and their significance. Histopathology. 2012;60(4):59-74.

4. Randolph TL, Amin MB, Ro JY, et al. Histologic variants of adenocarcinoma and other carcinomas of prostate: pathologic criteria and clinical significance. Mod Pathol. 1997;10(6):612-629.

5. Yoshimura K, Fukui I, Ishikawa Y, et al. Locally-confined signet-ring cell carcinoma of the prostate: a case report of a long-term survivor. Int J Urol. 1996;3(5):406-407.

6. Kanematsu A, Hiura M. Primary signet ring cell adenocarcinoma of the prostate treated by radical prostatectomy after preoperative androgen deprivation. Int J Urol. 1997;4(5):522-523. 
7. Ishizu K, Hirata H, Naito K, et al. Signet ring cell carcinoma of the prostate successfully treated with endocrine therapy: a case report). Hinyokika Kiyo. 2003;49(5):281-283.

8. Akagashi K, Tanda H, Kato S, et al. Signet-ring cell carcinoma of the prostate effectively treated with maximal androgen blockade. Int J Urol. 2003;10(8):456-458.

9. Fujita K, Sugao H, Gotoh T, et al. Primary signet ring cell carcinoma of the prostate: report and review of 42 cases. Int J Urol. 2004;11(3):178881.

10. Uemura M, Nakagawa M, Kanno N, et al. Signet ring-cell carcinoma of the prostate: a case report. Hinyokika Kiyo. 2004;50(9):645-647.

11. Derouiche A, Ouni A, Kourda N, et al. A new case of signet ring cell carcinoma of the prostate. Clin Genitourin Cancer. 2007;5(7):455-456.

12. Lilleby W, Axcrona K, Alfsen CG, et al. Diagnosis and treatment of primary signet-ring cell carcinoma of the prostate. Acta Oncol (Madr). 2007;46(8):1195-1197.

13. Matsuoka Y, Arai G, Ishimaru H, et al. Primary signet-ring cell carcinoma of the prostate. Can J Urol. 2007;14(6):3764-3766.

14. Warner JN, Nakamura LY, Pacelli A, et al. Primary Signet Ring Cell Carcinoma of the Prostate. Mayo Clin Proc. 2007;85(12): 1130-1136.

15. Hashimoto Y, Imanishi K, Okamoto A, et al. An Aggressive Signet Ring Cell Carcinoma of the Prostate in a Japanese Man. Case Rep Oncol. 2011;4(3): 517-520.
16. Bonetti LR, Lupi M, Stauder E, et al. An unusual case of signet ring cell adenocarcinoma of the prostate. Pathologica. 2011;103(2): 40-42.

17. Kwon WA, Oh TH, Ahn SH, et al. Primary signet ring cell carcinoma of the prostate. Can Urol Assoc J. 2013;7(11-12):768-771.

18. Celik O, Budak S, Ekin G, et al. A case with primary signet ring cell adenocarcinoma of the prostate and review of the literature. Arch Ital di Urol e Androl. 2014;86(2):148.

19. Kim SW, Kim W, Cho YH, et al. Primary signet ring cell carcinoma of the prostate treated by radical cystoprostatectomy and chemoradiotherapy. Can. Urol. Assoc. J. 2016;10(5-6): E204-E206.

20. Roldán AM, Núñez NF, Grande E, et al. A Primary Signet Ring Cell Carcinoma of the Prostate With Bone Metastasis With Impressive Response to FOLFOX and Cetuximab. Clin Genitourin Cancer. 2012;10(3):199-201.

21. Yamamoto S, Ito T, Akiyama A, et al. M1 prostate cancer with a serum level of prostate-specific antigen less than $10 \mathrm{ng} / \mathrm{mL}$. Int $J$ Urol. 2001;8(7):374-379.

22. Ro JY, Naggar EA, Ayala AG, et al. Signet-ring-cell carcinoma of the prostate. Electron-microscopic and immunohistochemical studies of eight cases. Am J Surg Pathol. 1988;129(6):453-460. 